\title{
Citrus Sudden Death Is Transmitted by Graft-Inoculation and Natural Transmission Is Prevented by Individual Insect-Proof Cages
}

\begin{abstract}
Pedro T. Yamamoto, Renato B. Bassanezi, Nelson A. Wulff, Mateus A. Santos, André L. Sanches, Rodrigo S. Toloy, Nelson Gimenes-Fernandes, and Antonio J. Ayres, Departamento Científico, Fundo de Defesa da Citricultura, Fundecitrus, Av. Dr. Adhemar Pereira de Barros, 201, CEP 14807-040, Araraquara - SP, Brazil; Waldir C. Jesus Junior, Laboratório de Fitopatologia, Departamento de Fitotecnia, Universidade Federal do Espírito Santo, Alto Universitário, S/N, CEP 29500-000, Alegre - ES, Brazil; Tatsuya Nagata, Departamento de Biologia Celular, IB4, Universidade de Brasília, ICC Ala Sul, Asa Norte, CEP 70910-900, Brasília - DF, Brazil; Francisco A. O. Tanaka and Elliot W. Kitajima, NAP/MEPA, Escola Superior de Agricultura "Luiz de Queiroz", Universidade de São Paulo, Av. Pádua Dias, 11, CEP 13418-900, Piracicaba - SP, Brazil; and Joseph M. Bové, Unité Mixte de Recherche en Génomique, Développement et Pouvoir Pathogène, Centre de Recherche INRA de Bordeaux, 71, Ave. Edouard Bourlaux, 33883 Villenave d'Ornon Cedex, France
\end{abstract}

\begin{abstract}
Yamamoto, P. T., Bassanezi, R. B., Wulff, N. A., Santos, M. A., Sanches, A. L., Toloy, R. S., Gimenes-Fernandes, N., Ayres, A. J., Jesus Junior, W. C., Nagata, T., Tanaka, F. A. O., Kitajima, E. W., and Bové, J. M. 2011. Citrus sudden death is transmitted by graft-inoculation and natural transmission is prevented by individual insect-proof cages. Plant Dis. 95:104-112.

Citrus sudden death (CSD) transmission was studied by graftinoculation and under natural conditions. Young sweet orange trees on Rangpur rootstock were used as indicator plants. They were examined regularly for one or two characteristic markers of CSD: (i) presence of a yellow-stained layer of thickened bark on the Rangpur rootstock, and (ii) infection with the CSD-associated marafivirus. Based on these two markers, transmission of CSD was obtained, not only when budwood for graft-inoculation was taken from symptomatic, sweet orange trees on Rangpur, but also when the budwood sources were asymptomatic sweet orange trees on Cleopatra mandarin, indicating that the latter

transmission, 80 young indicator plants were planted within a citrus plot severely affected by CSD. Individual insect-proof cages were built around 40 indicator plants, and the other 40 indicator plants remained uncaged. Only two of the 40 caged indicator plants were affected by CSD, whereas 17 uncaged indicator plants showed CSD symptoms and were infected with the marafivirus. An additional 12 uncaged indicator plants became severely affected with citrus variegated chlorosis and were removed. These results strongly suggest that under natural conditions, CSD is transmitted by an aerial vector, such as an insect, and that the cages protected the trees against infection by the vector.
\end{abstract} trees are symptomless carriers of the CSD agent. For natural

\begin{abstract}
"Morte Súbita dos Citros" or citrus sudden death (CSD) was first reported in 2001 in southwestern Minas Gerais State (MGS) and northern São Paulo State (SPS), Brazil (9), the largest region for production of sweet orange (Citrus sinensis (L.) Osb.) in the world. This new and destructive disease affects sweet orange as well as other species, varieties, and hybrids, such as Ponkan and Cravo mandarin (C. reticulata Blanco), Murcott tangor (C. sinensis $\times C$. reticulata), sweet lime $(C$. limettioides Tan.), and Tahiti lime (C. latifolia Tan.) when grafted on Rangpur (C. limonia Osb.). Most trees in SPS and MGS are grafted on Rangpur because under the conditions there citrus trees on this rootstock can be grown without irrigation $(9,12)$. Trees grafted on Volkamer lemon $(C$. volkameriana V. Tem. \& Pasq.) and rough lemon (C. jambhiri Lush.), natural substitutes for Rangpur, because they also confer drought resistance to sweet orange trees, are also affected by CSD (12; R. B. Bassanezi, unpublished).

For the following two reasons, CSD can be considered a budunion disease (12): (i) within severely affected blocks of sweet orange trees on Rangpur, trees of the same sweet orange cultivar
\end{abstract}

Corresponding author: R. B. Bassanezi

E-mail: rbbassanezi@ fundecitrus.com.br

Accepted for publication 31 August 2010.

doi:10.1094/PDIS-04-10-0307

(C) 2011 The American Phytopathological Society but grafted on different rootstocks such as Poncirus trifoliata (L.) Raf., Swingle citrumelo ( $P$. trifoliata $\times C$. paradisi Macf.), and Cleopatra (C. reticulata) and Sunki (C. sunki Hort.) mandarins, grow well and do not show CSD symptoms (9); and (ii) symptomatic trees in early stages of decline do recover when inarched with the latter rootstocks.

CSD-affected trees show: (i) generalized decline characterized by small, pale-green leaves throughout the canopy, (ii) increased defoliation, (iii) reduction in new shoots, (iv) absence of shoots inside the canopy, (v) rotting and death of large portions of the root system, and (vi) under certain conditions, trees suddenly decline, with the fruit and/or dry leaves remaining attached to the trees. Even though Rangpur as a rootstock is tolerant to Citrus tristeza virus (CTV) decline, these symptoms are similar to those of trees grafted onto sour orange rootstock ( $C$. aurantium L.) when infected with severe, quick-decline isolates of CTV (Closteroviridae) such as those present in SPS. However, a symptom specific to CSD can be seen in the rootstock bark, immediately below the bud union of all CSD-sensitive scion/rootstock combinations: the presence of a conspicuous yellow-stained layer either on the cambium side of the bark or within the bark (9). In addition, the Rangpur bark below the bud union of CSD-affected trees undergoes profound anatomical changes: reduction of functional phloem, occlusion, collapse, and necrosis of sieve tubes, and accumulation of nonfunctional phloem, which results in conspicuous thickening of the yellow-stained rootstock bark below the bud union (12). Very similar anatomical changes, except the yellow staining, occur in the sour orange bark below the bud union 
of quick decline trees affected by CTV $(12,15)$. The symptoms intensify as the disease progresses, and in the case of trees exposed to long periods of water deficit concomitant with a high fruit set, trees suddenly collapse and die. Tree death is much more frequent with Rangpur than with Volkamer or rough lemon rootstocks.

CSD is localized. The disease started in the southern part of the Triangulo Mineiro of southern MGS and the northern part of SPS, and continued to move southward until 2005, when it stopped, having reached latitude $21^{\circ}$ south (3). From 2005 to 2010, CSD has spread within the affected region, but has apparently not spread out of this region. It has been reported in 12 municipalities of MGS and 22 municipalities of SPS. The CSD-affected region was known prior to CSD as an area with limitations for citrus production because of a pronounced drought period (annual water deficit above $80 \mathrm{~mm}$ ) and an annual mean temperature higher than $22^{\circ} \mathrm{C}$ (14). However, CSD is not abiotic in nature since, as shown in this paper, the disease is transmissible by graft-inoculation as well as by an aerial vector(s), probably an insect, and therefore is infectious and biotic in nature as was previously suggested $(1,2)$. From 2001 to 2006 when the last official survey was carried out by Fundecitrus (Araraquara, SP), CSD has been responsible for the decline and elimination of almost four million trees, representing $10 \%$ of the 40 million trees in the affected region or $2 \%$ of the 200 million sweet orange trees in MGS and SPS (3). CSD continues to be a serious threat to the citrus production in the affected region.

Search for biotic agents possibly associated with CSD-affected trees, such as Phytophthora spp., fungi (Fusarium spp.), endogenous bacteria (Xylella fastidiosa, Candidatus Liberibacter spp., Spiroplasma citri, and Candidatus Phytoplasma spp.), viroids, and viruses (Luteovirus, Capillovirus, Trichovirus, Ilarvirus, Potyvirus, Begomovirus, Geminivirus, Cucumovirus, and Rimovirus) produced negative results $(1,4,12)$. Interestingly however, two viruses, a new marafivirus (Tymoviridae), tentatively called Citrus sudden death-associated virus $(\mathrm{CSDaV})(10)$, and CTV $(7,8,10,16-19)$, the latter known to be present in all citrus trees in SPS and MGS, have been found in CSD-affected trees. The respective role of these two viruses in CSD has not yet been elucidated.

Here we show that the putative agent(s) of CSD can be transmitted by graft inoculation. Previously, only preliminary results on graft transmission have appeared $(20,21)$. Also, 17 of 40 (40\%) sweet orange trees on Rangpur developed specific CSD symptoms when grown, unprotected from visiting insects, for 7 years in a CSD-affected field plot, whereas only 2 of $40(5 \%)$ of such trees showed symptoms when they were grown in the same plot but protected within individual insect-proof cages.

\section{Materials and Methods}

Experiment \#1. Transmission of CSD from sweet orange shoots to Rangpur rootstock seedlings. Rangpur seedlings were grown in an insect-proof screenhouse in Comendador Gomes municipality, southern MGS, a region severely affected by CSD. In April 2002, the seedlings were topped to a stem height of $\sim 40 \mathrm{~cm}$, and the topped stem end was approach-grafted with a $\sim 5-\mathrm{cm}-\mathrm{long}$ graft-connection to a sweet orange shoot with similar diameter on one of the following four adult Natal sweet orange trees: (\#1) CSD-affected tree on Rangpur; (\#2) symptomless tree on Cleopatra mandarin, both trees in a grove severely affected by CSD in Comendador Gomes municipality, MGS; and (\#3 and \#4), trees respectively on Rangpur and Cleopatra mandarin, at the Bebedouro Citrus Experimental Station (EECB), SPS, in the CSD-free region (Table 1). The roots of the approach-grafted seedlings were kept in plastic bags and maintained moist with wetted filter paper. When, after 60 days, the grafts had taken, the sweet orange shoots were cut off below the approach-grafts, yielding indicator plants in which the distal part of the shoot became a CSD-affected sweet orange scion, serving as the CSD-inoculum donor to the underlying Rangpur rootstock that served as the disease indicator. The indicator plants were maintained in a screenhouse under insect-proof conditions and were planted in 12-liter containers with a soil mix (3 parts clay soil, 1 part sand, 1 part cattle manure) from the CSD-free region (Araraquara municipality, SPS) to avoid interference by a putative soilborne CSD pathogen and/or vector. Eighteen to 20 approach-grafted plants were produced from each of the four Natal sweet orange trees. Periodically, the occurrence of CSD symptoms was assessed until the end of February 2007, 58 months after approach-grafting. Particular attention was given to the CSD-specific yellow staining and thickening of the rootstock bark below the graft-union. Examinations for pathological anatomy of the bud union bark of symptomatic and symptomless indicator plants were conducted according to Román et al. (12). Bark samples were collected in August 2006, $5 \mathrm{~cm}$ above and $5 \mathrm{~cm}$ below the bud union line.

Table 1. Natal sweet orange shoots approach-grafted to Rangpur rootstock seedlings (April 2002): transmission of citrus sudden death (CSD) from the shoot (scion) to the rootstock ${ }^{\mathrm{a}}$

\begin{tabular}{|c|c|c|c|c|c|c|}
\hline \multirow[b]{3}{*}{ Donor plants } & \multirow{3}{*}{$\begin{array}{c}\text { Location of shoot-donor sweet } \\
\text { orange trees }\end{array}$} & \multicolumn{5}{|c|}{ Plants with Natal sweet orange shoots on Rangpur rootstocks } \\
\hline & & \multirow[b]{2}{*}{ Total } & \multicolumn{3}{|c|}{$\begin{array}{l}\text { No. of symptomatic plants with yellow stain } \\
\text { in Rangpur bark (Cumulative) }\end{array}$} & \multirow[b]{2}{*}{ Final \% } \\
\hline & & & July 2003 & Jan. 2004 & Feb. 2007 & \\
\hline $\begin{array}{l}\text { 1. Natal/Rangpur } \\
\text { (symptomatic) }\end{array}$ & $\begin{array}{l}\text { CSD-affected region, } \\
\text { Comendador Gomes municipality }\end{array}$ & 19 & 3 & 5 & 6 & 32 \\
\hline $\begin{array}{l}\text { 2. Natal/Cleopatra } \\
\text { (asymptomatic) }\end{array}$ & $\begin{array}{l}\text { CSD-affected region, } \\
\text { Comendador Gomes municipality }\end{array}$ & 20 & 11 & 13 & 14 & 70 \\
\hline $\begin{array}{l}\text { 3. Natal/Rangpur } \\
\text { (asymptomatic) }\end{array}$ & $\begin{array}{l}\text { CSD-free region, } \\
\text { Bebedouro municipality }\end{array}$ & 18 & 0 & 0 & 0 & 0 \\
\hline $\begin{array}{l}\text { 4. Natal/Cleopatra } \\
\text { (asymptomatic) }\end{array}$ & $\begin{array}{l}\text { CSD-free region, } \\
\text { Bebedouro municipality }\end{array}$ & 20 & 0 & 0 & 0 & 0 \\
\hline
\end{tabular}

${ }^{a}$ Rangpur seedlings were approach-grafted to shoots of each of the four sweet orange trees.

Table 2. Transmission of citrus sudden death (CSD) to indicator plants (IP) by graft-inoculation (March 2002)

\begin{tabular}{|c|c|c|c|c|c|c|c|c|c|c|}
\hline \multirow[b]{2}{*}{$\begin{array}{l}\text { Source tree for } \\
\text { budwood inoc. }\end{array}$} & \multirow[b]{2}{*}{$\begin{array}{c}\text { Origin of } \\
\text { source tree }^{\mathrm{a}}\end{array}$} & \multirow[b]{2}{*}{ IP } & \multirow[b]{2}{*}{ No. of IP } & \multicolumn{6}{|c|}{$\begin{array}{l}\text { Cumulative no. of IP with yellow stain in rootstock bark } \\
\text { below bud union line }\end{array}$} & \multirow{2}{*}{$\begin{array}{c}\text { IP with } \\
\text { yellow stain } \\
\text { in rootstock } \\
\text { bark }(\%)\end{array}$} \\
\hline & & & & $\begin{array}{l}\text { May } \\
2003\end{array}$ & $\begin{array}{l}\text { Sep. } \\
2003\end{array}$ & $\begin{array}{l}\text { Jan. } \\
2004\end{array}$ & $\begin{array}{l}\text { May } \\
2004\end{array}$ & $\begin{array}{l}\text { Aug. } \\
2005\end{array}$ & $\begin{array}{l}\text { Mar. } \\
2007\end{array}$ & \\
\hline 1. Natal/Rangpur & C. Gomes & Pera/Rangpur & 27 & 1 & 1 & 1 & 2 & 2 & 2 & 7 \\
\hline 2. Natal/Cleopatra & C. Gomes & Pera/Rangpur & 27 & 3 & 6 & 7 & 7 & 8 & 8 & 30 \\
\hline 3. Natal/Rangpur & Bebedouro & Pera/Rangpur & 18 & 0 & 0 & 0 & 0 & 0 & 0 & 0 \\
\hline
\end{tabular}

${ }^{\text {a }}$ Comendador Gomes $=$ CSD-affected region; Bebedouro $=$ CSD-free region. 
Experiment \#2. Transmission of CSD by graft-inoculation to indicator plants of Pera sweet orange on Rangpur rootstock. Experiment \#2A. One-year-old Pera sweet orange trees grafted onto Rangpur (carrying CTV cross-protecting strain IAC-2) were produced in a closed, insect-proof nursery in the CSD-free region and used as indicator plants for CSD transmission by graft inoculation. Sources of budwood for graft inoculation were Natal sweet orange trees (\#1), (\#2), and (\#3) from the above paragraph (Table 2). Graft inoculations with budwood from the three source trees were carried out in 2002 and involved two buds and one budwood stick (with four buds) per indicator plant. One bud was grafted onto the sweet orange scion of the indicator plant, and the second onto the Rangpur rootstock; whereas the budstick was approach-grafted onto the middle part of the scion (Fig. 1A). The first two treatments had 27 replications, the third only 18 (Table 2). All indicator plants were planted in 12-liter containers with substrate prepared with soil from the CSD-free region (see above), sprayed with systemic insecticides, and treated with soil applications of aldicarb and thiamethoxam, even though they were kept in insect-proof screenhouses to assure freedom from insects. The indicator plants were observed for the CSD-specific yellow staining and thickening of the rootstock-bark below the bud union line. The first observations began in May 2003, 14 months after graft inoculation (Fig. 1B), and were repeated thereafter every 4 months until the end of March 2007, 60 months after graft inoculation.

Experiment \#2B. The experiment involved 120 1-year-old Pera sweet orange trees on Rangpur (harboring cross-protecting CTV strain IAC-2) from a closed, insect-proof nursery. In June 2006, 40 of these indicator plants were graft-inoculated with budwood sticks (3 buds per stick) from an adult Valencia sweet orange tree on Rangpur in the CSD-free region (EECB Bebedouro municipality); the tree tested negative for the marafivirus when budwood sticks were collected. Twenty indicator plants were not inoculated. The other 60 indicator plants were graft-inoculated with budwood sticks ( 3 buds per stick) from an adult Natal sweet orange tree on
Cleopatra mandarin from the CSD-affected region (Comendador Gomes municipality). The Natal tree tested positive for the marafivirus when the budwood sticks were collected. All 120 indicator plants were grown in 12-liter containers with pine bark substrate (Rendmax Citrus, Eucatex, SPS) in an insect-proof screenhouse. All indicator plants were analyzed, as indicated below, for CTV and marafivirus infections in August 2009, 38 months after graft inoculation.

Detection of CTV and the marafivirus. After assessing the presence or absence of the CSD-specific yellow staining and thickening of the Rangpur portion of the bark, a $0.5-\mathrm{cm}$-wide, rectangular piece of bark was removed from each indicator plant extending $1.5 \mathrm{~cm}$ above and $1.5 \mathrm{~cm}$ below the bud union. The bark samples were stored at $-80^{\circ} \mathrm{C}$ for a few weeks. Next, each piece of bark was sliced into small sections with a razor blade and $500 \mathrm{mg}$ were used for total RNA extraction after grinding in liquid $\mathrm{N}_{2}$. Total RNA was extracted with Trizol LS reagent (Invitrogen) according to the manufacturer's instructions. The final RNA pellet was resuspended in $30 \mu \mathrm{l}$ of sterile water treated with $0.1 \%$ diethyl pyrocarbonate (DEPC, Sigma) and either used immediately or stored at $-20^{\circ} \mathrm{C}$. First-strand cDNA was synthesized with ImpromII reverse transcriptase $(1 \mu \mathrm{l}$, Promega) with $1 \mu \mathrm{l}$ total RNA, $1 \mu \mathrm{l}$ RNase OUT (Invitrogen), $0.5 \mu \mathrm{M}$ random hexamer primer, 0.25 $\mathrm{mM}$ dNTPs, $1 \times$ ImpromII buffer, $3 \mathrm{mM} \mathrm{MgCl}_{2}$ in $20 \mu \mathrm{l}$ final volume according to the manufacturer's instructions. Polymerase chain reaction (PCR) was performed in duplex using 1.0 $\mu \mathrm{l} \mathrm{cDNA}$, $1 \times$ Phire buffer, $0.2 \mathrm{mM}$ dNTPs, $0.5 \mu \mathrm{M}$ of each forward and reverse primer, and $0.4 \mu \mathrm{l}$ of Phire hot start DNA polymerase (Finnzymes) in a final reaction mixture of $20 \mu \mathrm{l}$. The PCR conditions were as follows: a denaturation step at $98^{\circ} \mathrm{C}$ for $1 \mathrm{~s}$ and 35 amplification cycles $\left(5 \mathrm{~s}\right.$ at $98^{\circ} \mathrm{C}, 30 \mathrm{~s}$ at $69^{\circ} \mathrm{C}$, and $20 \mathrm{~s}$ at $72^{\circ} \mathrm{C}$ ) with a final extension step of $2 \mathrm{~min}$ at $72^{\circ} \mathrm{C}$. PCR product was electrophoresed in $1.0 \%$ agarose gel at $1 \times \mathrm{TAE}$ and visualized under UV light after ethidium bromide staining. Detection of the marafivirus was performed using newly defined primers C1_For and Geno_Rev, 5'CCGCTGTCACCATTGCTTCCAG3' and

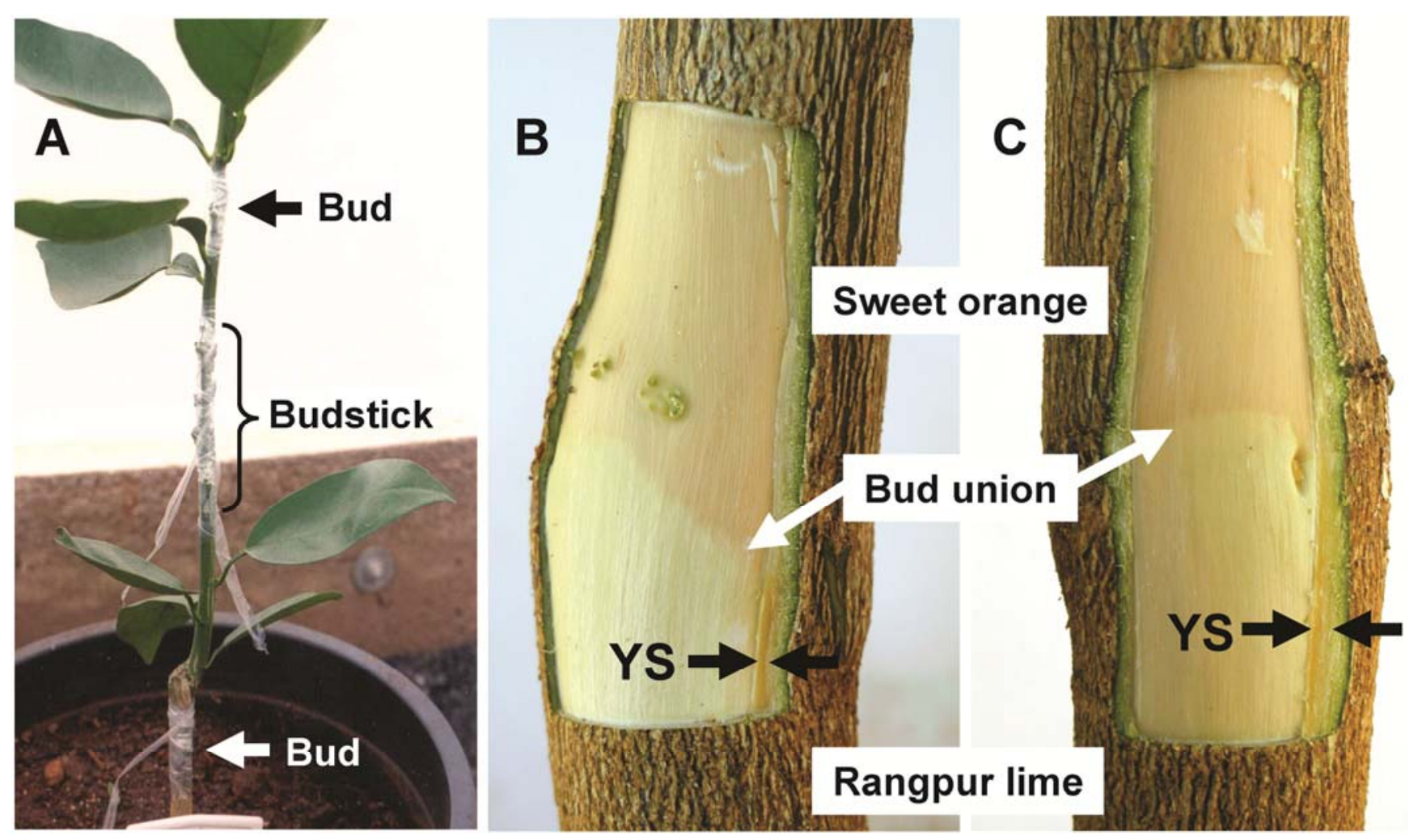

Fig. 1. Transmission of citrus sudden death by graft-inoculation to indicator plants (Pera sweet orange on Rangpur). A, Graft-inoculation of one bud onto the scion of the indicator plant, the second bud onto the rootstock; one budstick with four buds was approach-grafted onto the middle part of the scion. B and C, Yellow stain (YS) within the inner layer of Rangpur rootstock bark, 14 months after graft-inoculation. 

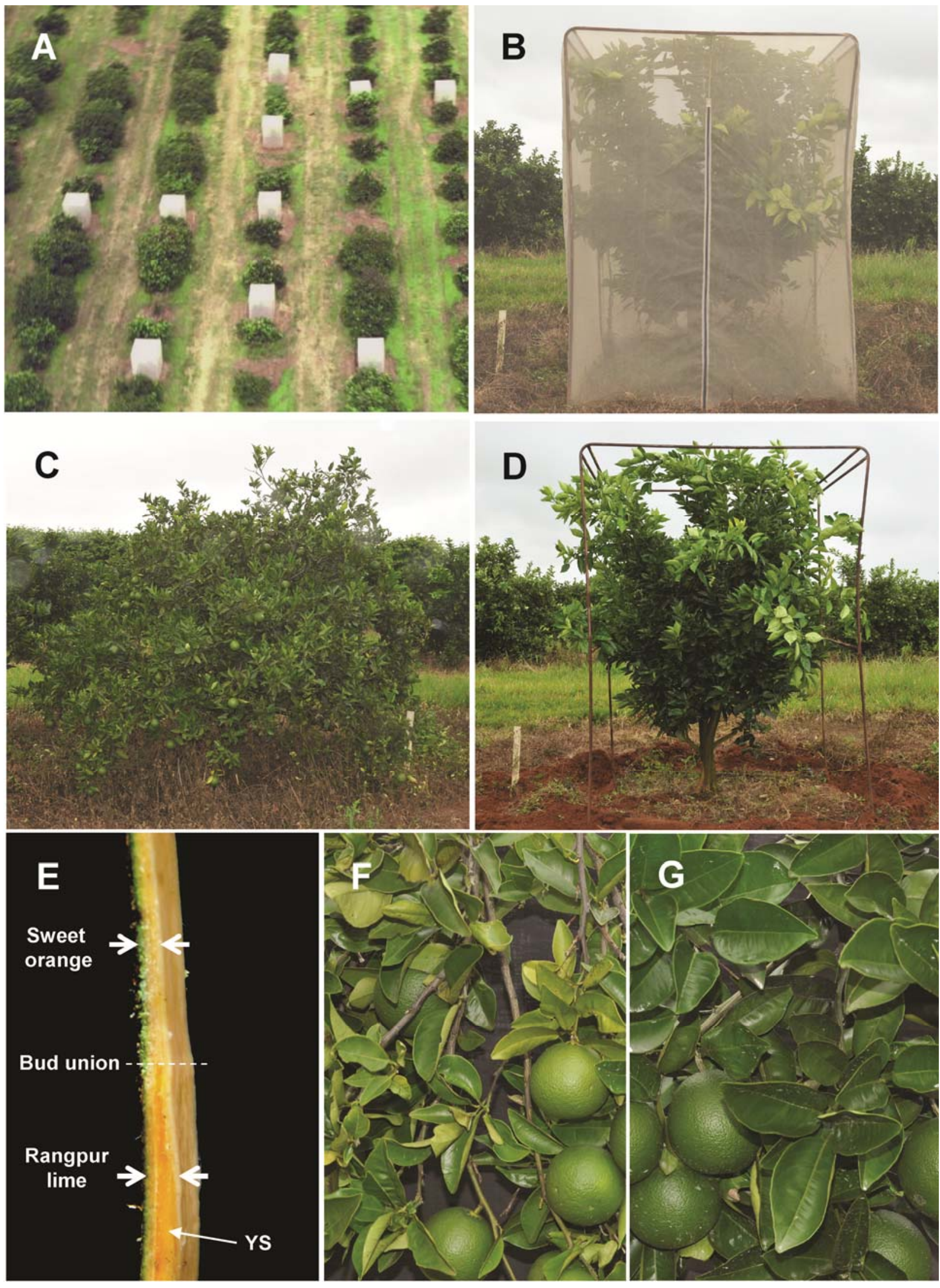

Fig. 2. Natural transmission of citrus sudden death (CSD). A, Aerial view of individual insect-proof cages in CSD-affected field plot. B, Natal sweet orange tree on Rangpur within individual, insect-proof cage. C, CSD-affected Natal sweet-orange tree on Rangpur grown unprotected in the open (without cage). D, Symptomless Natal sweet orange on Rangpur grown within insect-proof cage, after removal of screen. E, Bark from bud union line of CSD-affected Natal sweet orange tree on Rangpur showing yellow stain within, and increased thickness of, rootstock bark. F, Small, pale leaves of CSD-affected Natal sweet orange tree grown unprotected in the open (without cage). G, Normal, bright green leaves of symptomless Natal sweet orange tree on Rangpur. Photo A was taken in 2006, 4 years after planting. Photos B to G were taken in 2010, 8 years after planting. 
5'GGGAACTCATTGTGGAACCAGTCA3', respectively, resulting in a 246-bp product. The sequence of this product had $99 \%$ identity with the corresponding sequence of the CSD-associated marafivirus (10). CTV was detected with primers CN119 and CN120 (13).

Experiment \#3. Natural spread of CSD tested by growing trees in the field in individual insect-proof cages or unprotected. One-year-old Natal and Pera sweet orange test trees on Rangpur were produced in an insect-proof, closed nursery. In May 2002, 40 trees of each variety were planted arbitrarily within a block of sweet orange trees on Rangpur in Comendador Gomes municipality, MGS. Trees severely affected by CSD in this block were removed and replaced by the 40 Natal sweet orange trees and the 40 Pera sweet orange trees. Finally, individual insect-proof cages were built around 20 trees of each variety (Fig. 2A). The cages measured $170 \mathrm{~cm}$ wide $\times 170 \mathrm{~cm}$ long $\times 250 \mathrm{~cm}$ high and were covered with anti-aphid screen of mesh 50 (opening: $0.28 \times$ $0.85 \mathrm{~mm}$ ) (Fig. 2B). The screen over the cages had to be replaced every 2 years, a 30-min operation during which the trees remained unprotected and were therefore sprayed with organophosphate insecticides. Other operations such as fertilizer applications, pruning, or weed control also required the cages to be opened, approximately once a month, and were followed by insecticide sprays. Holes in the screen were repaired as soon as noticed. Some of the cages were occasionally damaged during stormy weather and had to be treated with insecticide until repaired. Finally, the caged trees received a once-a-year soil application of thiamethoxam, a systemic insecticide. All trees were analyzed for CTV and marafivirus infections in leaves and bark in February 2008, 69 months after planting. A 1-cm-wide, rectangular piece of bark was removed from each tree, $2 \mathrm{~cm}$ above and $2 \mathrm{~cm}$ below the bud union line, and the presence or absence of the CSD-specific yellow stain in the Rangpur portion of the bark was assessed. Treatment of the bark samples and RNA extraction were as indicated above. First-strand cDNA synthesis was also as above, except that the specific reverse primers CN120 for CTV (13) and Com_R (newly defined) for the marafivirus were used. PCR was performed individually for each virus, using $1.0 \mu \mathrm{l} \mathrm{cDNA}, 1 \times$ Platinum Taq buffer, $0.2 \mathrm{mM}$ dNTPs, $0.5 \mu \mathrm{M}$ of each forward and reverse primer, and $1 \mathrm{U}$ of Platinum Taq DNA polymerase (Invitrogen) in a $20-\mu \mathrm{l}$ final volume of reaction mixture. Detection of a 622-bp amplicon from the marafivirus was performed using primers Com_F (5'ATGGTCTCAGGCGACGACTCCCT3') and Com_R (5'GTGAGGATGGGAGCAGAGGAAC3'). CTV was detected with primers CN119 and CN120 (13). The PCR conditions were as follows: a denaturation step at $94^{\circ} \mathrm{C}$ for $2 \mathrm{~min}$ and 35 amplification cycles $\left(30 \mathrm{~s}\right.$ at $94^{\circ} \mathrm{C}, 60 \mathrm{~s}$ at $69^{\circ} \mathrm{C}$, and $60 \mathrm{~s}$ at $72^{\circ} \mathrm{C}$ ) with a final extension step of $10 \mathrm{~min}$ at $72^{\circ} \mathrm{C}$. The PCR product was electrophoresed in $1.2 \%$ agarose gel at $1 \times$ TAE and visualized under UV light after ethidium-bromide staining.

\section{Results}

Experiment \#1. Transmission of CSD from sweet orange shoots to Rangpur rootstock seedlings. When the CSD transmission experiments aimed at determining if CSD was caused by a graft-transmissible agent were initiated, it was thought that a graft inoculum as large as possible could increase the possibility of transmission. Therefore, Rangpur seedlings were approach-grafted to shoots of various donor sweet orange trees in April 2002 (Table 1). When, after 60 days, the grafts had taken, the Rangpur seedlings were disconnected from the sweet orange donor tree by cutting the sweet orange shoots below the graft-union. In the resulting indicator plant, the rooted part of the initial Rangpur seedling was now carrying as a scion the distal end of the approach-grafted, CSD-affected Natal sweet orange shoot.

Table 1 shows that, indeed, when the sweet orange scion-shoots came from a symptomatic, CSD-affected Natal sweet orange tree on Rangpur (tree \#1) in the CSD-affected region, the Rangpur rootstock bark of six indicator plants showed the yellow staining and thickening specific to CSD by February 2007, 60 months after approach-grafting. The first symptoms were observed in July 2003 , 15 months after approach-grafting. Interestingly, sweet orange scion-shoots of a symptomless Natal sweet orange tree on Cleopatra mandarin (tree \#2) from the same citrus block as tree \#1 also resulted in the development of the yellow staining and thickening in the Rangpur rootstock bark of 14 indicator plants. As expected, the yellow staining and bark thickening were absent from all 38 indicator plants with sweet orange scion-shoots from the two trees in the CSD-free region (trees \#3 and \#4). With symptomless tree \#2, 70\% of indicator plants (14 of 20) showed CSD symptoms, whereas with the symptomatic tree \#1, only $32 \%$ of indicator plants (6 of 19) were CSD-positive. Examination of bud union bark of symptomatic indicator plants revealed the same pathological anatomy of sweet orange bark (5 $\mathrm{cm}$ above bud union line) and Rangpur bark ( $5 \mathrm{~cm}$ below bud union line) as that described by Román et al. (12). Bark of symptomless indicator plants was normal.

Experiment \#2. Transmission of CSD by graft inoculation to indicator plants of Pera sweet orange on Rangpur rootstock. Experiment \#2A. In the experiment in Table 2, Pera sweet orange trees on Rangpur were used as indicator plants for transmission of CSD by classic graft inoculation, using two buds and one budstick as inoculum (Fig. 1A). Two of the source trees for inoculum were from the CSD-affected region (Table 2, trees \#1 and \#2), and the third tree was from the CSD-free region (Table 2, tree \#3). The results were similar to those in Table 1. Yellow staining and thickening of the Rangpur rootstock bark was observed only with the two source trees from the CSD-affected region (trees \#1 and $\# 2$ ), and the percentage of indicator plants with yellow stain was higher ( 8 of $27,30 \%$ ) for the symptomless Natal sweet orange source tree on Cleopatra mandarin (tree \#2) than for the symptomatic Natal sweet orange source tree on Rangpur (tree \#1) ( 2 of $27,7 \%$ ).

Experiment \#2B. In the experiment in Table 3, only symptomless Natal sweet orange trees on Cleopatra mandarin (trees \#1) from the CSD-affected region were used as the source trees for CSDpositive budwood inoculum. The amount of budwood required for the inoculations made it necessary to collect budwood from several such source trees. At the time of budwood collection (June 2006), all these trees were confirmed to be infected with CTV as well as

Table 3. Transmission of citrus sudden death (CSD) to Pera sweet orange on Rangpur indicator plants (IP) by graft-inoculation (June 2006) and detection of Citrus tristeza virus (CTV) and marafivirus in the plants (August 2009)

\begin{tabular}{|c|c|c|c|c|c|c|}
\hline \multirow{2}{*}{$\begin{array}{l}\text { Source tree } \\
\text { for budwood inoculum }\end{array}$} & \multirow[b]{2}{*}{ No. of IP } & \multicolumn{3}{|c|}{$\begin{array}{c}\text { Combination of CSD symptom and virus presence } \\
\text { in IP rootstock bark } \\
\end{array}$} & \multirow{2}{*}{$\begin{array}{c}\begin{array}{c}\text { No. of IP } \\
\text { for each } \\
\text { combination }\end{array} \\
\end{array}$} & \multirow{2}{*}{$\begin{array}{l}\text { \% of IP for each } \\
\text { combination }\end{array}$} \\
\hline & & Yellow stain & CTV & Marafivirus & & \\
\hline \multirow{3}{*}{$\begin{array}{l}\text { 1. Natal on Cleopatra in CSD- } \\
\text { affected region (Comendador } \\
\text { Gomes municipality) }\end{array}$} & \multirow[t]{3}{*}{60} & + & + & + & 36 & 60 \\
\hline & & - & + & + & 23 & 38 \\
\hline & & - & + & - & 1 & 2 \\
\hline $\begin{array}{l}\text { 2. Valencia on Rangpur in CSD-free } \\
\text { region (Bebedouro municipality) }\end{array}$ & 40 & - & + & - & 40 & 100 \\
\hline 3. No graft-inoculation & 20 & - & + & - & 20 & 100 \\
\hline
\end{tabular}


the marafivirus associated with CSD (10). Valencia sweet orange trees on Rangpur (trees \#2) were chosen in the CSD-free region as source trees for CSD-negative budwood. One-year-old Pera sweet orange trees on Rangpur were used as indicator plants for CSD and bark graft-inoculated on the Pera sweet orange scion with budwood sticks from the above source trees. In August 2009, 38 months after graft inoculation, the indicator plants were examined for yellow staining and thickening of the bark of the Rangpur rootstocks, and they were analyzed for the presence of both CTV and the marafivirus.

CTV was present in all 120 indicator plants (Table 3). Thirty-six of the 60 indicator plants (60\%) inoculated with CSD-positive budsticks (Table 3, source trees \#1) had the two CSD markers: (i) yellow staining and thickening of the rootstock bark, and (ii) presence of the marafivirus (Fig. 3). Interestingly, an additional 23 indicator plants $(38 \%)$ did not show the Rangpur bark symptoms but were positive for the marafivirus, bringing the total number of marafivirus-positive indicator plants to 59 of 60 , a very high

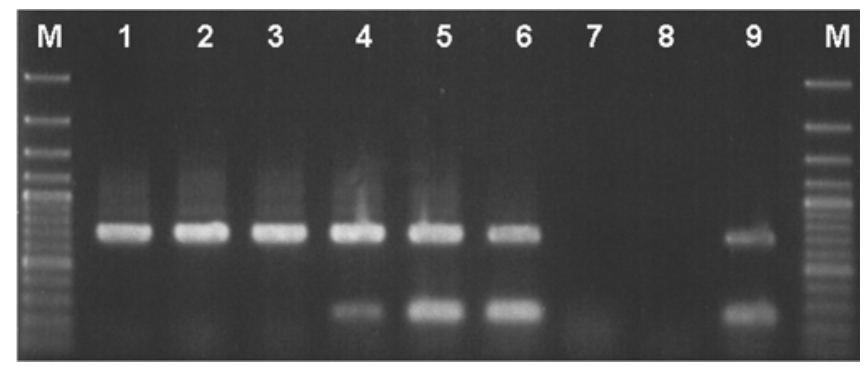

Fig. 3. Electrophoresis, on $1 \%$ agarose gel, of cDNA amplified by duplex polymerase chain reaction with primers $\mathrm{CN} 119$ and $\mathrm{CN} 120$ for Citrus tristeza virus, and C1_For and Geno_Rev for marafivirus, from total RNA extracted from bark samples. Lanes 1, 2, and 3: indicator plants graft-inoculated with budwood from a citrus sudden death (CSD)-free region; lanes 4, 5, and 6: indicator plants graftinoculated with budwood from CSD-affected region; lane 7: healthy sweet orange seedling; lane 8: no template in reaction mixture; lane 9: CSD-affected plant used as positive control. percentage of transmission. The 40 indicator plants inoculated with CSD-free budwood from trees \#2 and the 20 noninoculated indicator plants were free of yellow staining and thickening of the rootstock bark, and the marafivirus was not detected in these plants.

Experiment \#3. Natural spread of CSD to test trees growing in the field in individual insect-proof cages or unprotected. Finally, in a commercial orchard of the CSD-affected region, natural spread of CSD to sweet orange trees on Rangpur was studied under field conditions. The experiment involved 40 Natal (Table 4) and 40 Pera (Table 5) sweet orange test trees on Rangpur. Half of the test trees were caged individually within insect-proof screen cages (Fig. 2B), whereas the other half of the test trees remained uncaged (Fig. 2C). The test trees were planted arbitrarily in May 2002 and examined 69 months later, in February 2008, for yellow staining and thickening of the Rangpur rootstock bark as well as the presence of CTV and the marafivirus in the leaves and bud union bark. All 80 test trees were CTV-positive as the Natal and Pera sweet orange cultivars carried a protective CTV isolate against stem pitting CTV. Thirty-eight of 40 caged test trees were symptomless (Fig. 2D and G). Only one test tree (\#8) of the 20 caged Natal sweet orange trees and one test tree (\#18) of the 20 caged Pera sweet orange trees became affected by CSD based on the yellow staining and thickening of the Rangpur rootstock bark and infection with the marafivirus. None of the caged trees showed symptoms of citrus variegated chlorosis (CVC), indicating that within the cages they were well protected against Xylella fastidiosa-carrying sharpshooter vectors. In comparison, three of the uncaged Natal sweet orange trees (Table 4) and nine of the uncaged Pera sweet orange trees (Table 5) had to be removed because of severe symptoms of CVC. Of the remaining 17 uncaged Natal sweet orange trees and 11 uncaged Pera sweet orange trees, 9 and 8, respectively, were affected by CSD based on symptoms (Fig. 2C, E, and F) and the presence of marafivirus.

\section{Discussion}

CSD is a disease of sweet orange trees grafted on Rangpur, and on CSD-affected trees, the Rangpur bark below the bud union

Table 4. Natural transmission of citrus sudden death to Natal sweet orange trees on Rangpur growing in the field either protected within individual insectproof cages or unprotected in the open field

\begin{tabular}{|c|c|c|c|c|c|c|c|c|c|c|c|c|c|}
\hline \multicolumn{7}{|c|}{ Trees within insect-proof cages } & \multicolumn{7}{|c|}{ Trees without insect-proof cages } \\
\hline \multirow[b]{3}{*}{ Tree \# } & \multicolumn{4}{|c|}{ Detection $^{\text {a }}$} & \multicolumn{2}{|c|}{ Symptoms } & \multirow[b]{3}{*}{ Tree \# } & \multicolumn{4}{|c|}{ Detection } & \multicolumn{2}{|c|}{ Symptoms } \\
\hline & \multicolumn{2}{|c|}{$\mathrm{CTV}^{\mathbf{b}}$ in } & \multicolumn{2}{|c|}{ Marafivirus in } & \multirow{2}{*}{$\begin{array}{c}\text { Pale } \\
\text { leaves }\end{array}$} & \multirow{2}{*}{$\begin{array}{l}\text { Yellow } \\
\text { stain }^{c}\end{array}$} & & \multicolumn{2}{|c|}{ CTV in } & \multicolumn{2}{|c|}{ Marafivirus in } & \multirow{2}{*}{$\begin{array}{l}\text { Pale } \\
\text { leaves }\end{array}$} & \multirow{2}{*}{$\begin{array}{c}\text { Yellow } \\
\text { stain }\end{array}$} \\
\hline & Leaves & Bark & Leaves & Bark & & & & Leaves & Bark & Leaves & Bark & & \\
\hline 1 & + & + & - & - & - & - & 1 & + & + & - & - & - & - \\
\hline 2 & + & + & - & - & - & - & 2 & + & + & - & - & - & - \\
\hline 3 & + & + & - & - & - & - & 3 & + & + & + & + & + & +++ \\
\hline 4 & + & + & - & - & - & - & 4 & + & + & + & + & + & + \\
\hline 5 & + & + & - & - & - & - & 5 & + & + & + & + & + & ++ \\
\hline 6 & + & + & - & - & - & - & 6 & + & + & - & - & - & - \\
\hline 7 & + & + & - & - & - & - & 7 & + & + & - & - & - & - \\
\hline 8 & + & + & + & + & - & + & 8 & + & + & - & - & - & - \\
\hline 9 & + & + & - & - & - & - & 9 & \multicolumn{6}{|c|}{ Removed CVC ${ }^{\mathrm{d}}$-affected tree } \\
\hline 10 & + & + & - & - & - & - & 10 & + & + & + & + & + & + \\
\hline 11 & + & + & - & - & - & - & 11 & + & + & - & - & - & - \\
\hline 12 & + & + & - & - & - & - & 12 & + & + & + & + & + & +++ \\
\hline 13 & + & + & - & - & - & - & 13 & + & + & + & + & + & +++ \\
\hline 14 & + & + & - & - & - & - & 14 & + & + & + & + & + & ++++ \\
\hline 15 & + & + & - & - & - & - & 15 & + & + & + & + & + & ++ \\
\hline 16 & + & + & - & - & - & - & 16 & \multicolumn{6}{|c|}{ Removed CVC-affected tree } \\
\hline 17 & + & + & - & - & - & - & 17 & + & + & - & - & - & - \\
\hline 18 & + & + & - & - & - & - & 18 & + & + & + & + & + & ++ \\
\hline 19 & + & + & - & - & - & - & 19 & \multicolumn{6}{|c|}{ Removed CVC-affected tree } \\
\hline 20 & + & + & - & - & - & - & 20 & + & + & - & - & - & - \\
\hline & $20 / 20$ & $20 / 20$ & $1 / 20$ & $1 / 20$ & $0 / 20$ & $1 / 20$ & & $17 / 17$ & $17 / 17$ & $9 / 17$ & $9 / 17$ & $9 / 17$ & $9 / 17$ \\
\hline
\end{tabular}

\footnotetext{
a $+=$ yes; $-=$ no.

b Citrus tristeza virus.

c Yellow stain in rootstock bark

${ }^{\mathrm{d}}$ Citrus variegated chlorosis.
} 
shows a conspicuous yellow layer and an increased thickness specific to CSD $(9,12)$. Hence, to study CSD graft transmission, Natal or Pera sweet orange trees grafted on Rangpur were the obvious indicator plants. Two CSD markers have been used to study transmission of the disease to these indicator plants: (i) yellow staining and thickening of the Rangpur rootstock bark, and (ii) presence of the CSD-associated marafivirus (10). In the first two experiments (\#1 and \#2A), only the Rangpur rootstock bark marker was used; in the third and fourth experiments (\#2B and \#3), both markers were utilized and the presence of CTV was also assessed. Indeed, in SPS, CTV is spread by the aphid Toxoptera citricida and is present in all outdoor citrus trees, including the trees that were used as CSD-positive or CSD-negative budwood sources for inoculation. In addition, the 1-year-old Pera and Natal sweet orange trees on Rangpur used as indicator plants were infected with a protective CTV isolate against tristeza stem pitting. Hence, all the experimental trees involved in the transmission studies carried CTV isolates.

In the CSD-affected region, many sweet orange trees on Rangpur show symptoms of CSD, but all sweet orange trees on Cleopatra mandarin (and other rootstocks such as Sunki mandarin and Swingle citrumelo) are symptomless. Therefore, the outcome of the first transmission experiment where Rangpur seedlings were approach-grafted to shoots on Natal sweet orange trees was surprising. Indeed, the resulting indicator plants developed the CSD-characteristic yellow staining and bark thickening, indicating that they had become affected with CSD, not only when the sweet orange shoot donor trees were grafted on Rangpur and showed symptoms of CSD, but also when they were on Cleopatra mandarin and showed no symptoms of CSD. In addition, with the symptomless donor trees on Cleopatra mandarin, the percentage of CSD-positive indicator plants reached $70 \%$, whereas with the symptomatic trees on Rangpur, only $32 \%$ of indicator plants showed CSD symptoms (Table 1). Similar experiments were done with Rangpur seedlings approach-grafted to shoot-donor trees on Rangpur or Cleopatra mandarin in the CSD-free region. As expected, none of the resulting indicator plants developed the yellow staining and bark thickening.
In subsequent experiments (\#2A and \#2B), instead of approachgrafting Rangpur seedlings to shoot-donor trees, 1-year-old Pera sweet orange trees on Rangpur were used as indicator plants and graft-inoculated with buds and/or budsticks from various source trees. As above, the yellow staining and thickening of Rangpur rootstock bark developed on several indicator plants, indicating that they were CSD-positive, and the percentage of CSD-positive indicator plants was higher $(30 \%)$ when the graft inoculum came from symptomless Natal sweet orange trees on Cleopatra mandarin rather than from symptomatic Natal sweet orange trees on Rangpur (7\%) (Table 2). Again, all indicator plants inoculated with budwood from the CSD-free region remained CSD-free.

The above results demonstrate that, indeed, the symptomless Natal sweet orange tree on Cleopatra mandarin rootstock, whose budwood was able to induce CSD symptoms on the Rangpur rootstock bark of graft-inoculated indicator plants, was infected with the CSD agent, and this agent was transmitted from the graft inoculum to the indicator plants, which developed CSD. Since the CSD-infected Natal sweet orange trees on Cleopatra mandarin show no symptoms of CSD, as had already been concluded previously and confirmed here, this shows that Cleopatra mandarin forms a rootstock/scion combination with sweet orange that is tolerant to CSD, and that CSD is a bud union disease $(5,12)$. Therefore, Cleopatra mandarin can be used as a rootstock to control CSD or to inarch and save young trees on Rangpur (5). Apparently, the putative CSD-agent multiplies better in the CSDtolerant, symptomless sweet orange tree on Cleopatra mandarin and reaches higher titers than in the CSD-affected tree on Rangpur. This may explain the higher percentage of transmission with budwood from the symptomless trees on Cleopatra mandarin than with budwood from symptomatic trees on Rangpur.

Sweet orange indicator plants on Rangpur that develop yellow staining and thickening of the Rangpur rootstock bark upon inoculation of CSD-positive budwood material are considered to be affected by CSD, as these bark symptoms are characteristic of CSD. The same is not true for indicator plants positive for marafivirus but negative for bark symptoms, as the marafivirus is only known to be associated with CSD, its role in CSD being yet

Table 5. Natural transmission of citrus sudden death to Pera sweet orange trees on Rangpur growing in the field either protected within individual insectproof cages or unprotected in the open field

\begin{tabular}{|c|c|c|c|c|c|c|c|c|c|c|c|c|c|}
\hline \multirow[b]{4}{*}{ Tree \# } & \multicolumn{6}{|c|}{ Trees within insect-proof cages } & \multicolumn{7}{|c|}{ Trees without insect-proof cages } \\
\hline & \multicolumn{4}{|c|}{ Detection $^{a}$} & \multicolumn{2}{|c|}{ Symptoms } & & \multicolumn{4}{|c|}{ Detection } & \multicolumn{2}{|c|}{ Symptoms } \\
\hline & \multicolumn{2}{|c|}{$\mathrm{CTV}^{\mathbf{b}}$ in } & \multicolumn{2}{|c|}{ Marafivirus in } & \multirow{2}{*}{$\begin{array}{c}\text { Pale } \\
\text { leaves }\end{array}$} & \multirow{2}{*}{$\begin{array}{l}\text { Yellow } \\
\text { stain }^{c}\end{array}$} & \multirow[b]{2}{*}{ Tree \# } & \multicolumn{2}{|c|}{ CTV in } & \multicolumn{2}{|c|}{ Marafivirus in } & \multirow{2}{*}{$\begin{array}{l}\text { Pale } \\
\text { leaves }\end{array}$} & \multirow{2}{*}{$\begin{array}{r}\text { Yellow } \\
\text { stain }\end{array}$} \\
\hline & Leaves & Bark & Leaves & Bark & & & & Leaves & Bark & Leaves & Bark & & \\
\hline 1 & + & + & - & - & - & - & 1 & + & + & + & + & + & ++ \\
\hline 2 & + & + & - & - & - & - & 2 & + & + & + & + & - & + \\
\hline 3 & + & + & - & - & - & - & 3 & \multicolumn{6}{|c|}{ Removed CVC ${ }^{\mathrm{d}}$-affected tree } \\
\hline 4 & + & + & - & - & - & - & 4 & + & + & + & + & + & +++ \\
\hline 5 & + & + & - & - & - & - & 5 & \multicolumn{6}{|c|}{ Removed CVC-affected tree } \\
\hline 6 & + & + & - & - & - & - & 6 & + & + & - & - & - & - \\
\hline 7 & + & + & - & - & - & - & 7 & + & + & + & + & + & +++ \\
\hline 8 & + & + & - & - & - & - & 8 & \multicolumn{6}{|c|}{ Removed CVC-affected tree } \\
\hline 9 & + & + & - & - & - & - & 9 & + & + & + & + & + & ++++ \\
\hline 10 & + & + & - & - & - & - & 10 & + & + & + & + & + & ++ \\
\hline 11 & + & + & - & - & - & - & 11 & + & + & + & + & + & ++++ \\
\hline 12 & + & + & - & - & - & - & 12 & + & + & - & - & - & - \\
\hline 13 & + & + & - & - & - & - & 13 & \multicolumn{6}{|c|}{ Removed CVC-affected tree } \\
\hline 14 & + & + & - & - & - & - & 14 & \multicolumn{6}{|c|}{ Removed CVC-affected tree } \\
\hline 15 & + & + & - & - & - & - & 15 & \multicolumn{6}{|c|}{ Removed CVC-affected tree } \\
\hline 16 & + & + & - & - & - & - & 16 & + & + & + & + & + & ++++ \\
\hline 17 & + & + & - & - & - & - & 17 & \multicolumn{6}{|c|}{ Removed CVC-affected tree } \\
\hline 18 & + & + & + & + & - & + & 18 & \multicolumn{6}{|c|}{ Removed CVC-affected tree } \\
\hline 19 & + & + & - & - & - & - & 19 & + & + & - & - & - & - \\
\hline 20 & + & + & - & - & - & - & 20 & \multicolumn{6}{|c|}{ Removed CVC-affected tree } \\
\hline & $20 / 20$ & $20 / 20$ & $1 / 20$ & $1 / 20$ & $0 / 20$ & $1 / 20$ & & $11 / 11$ & $11 / 11$ & $8 / 11$ & $8 / 11$ & $7 / 11$ & $8 / 11$ \\
\hline
\end{tabular}

\footnotetext{
a $+=$ yes; $-=$ no.

b Citrus tristeza virus.

c Yellow stain in rootstock bark

${ }^{\mathrm{d}}$ Citrus variegated chlorosis.
} 
uncertain. However, since inoculated indicator plants with bark symptoms are always marafivirus positive, while indicator plants positive for marafivirus are not always positive for bark symptoms, the marafivirus is probably an earlier indicator of CSD than the bark symptoms. Similarly, Maccheroni et al. (10) detected the presence of marafivirus on 33 asymptomatic trees grafted on Rangpur in the CSD-affected region, and half of these positive trees became symptomatic 7 months later.

In the experiment on natural transmission of CSD to Pera and Natal sweet orange indicator plants on Rangpur, nine of the 17 uncaged Natal sweet orange indicator plants and eight of the 11 uncaged Pera sweet orange indicator plants became affected with CSD within the 69 months. The $17(9+8)$ CSD-affected indicator plants $(60 \%)$ showed, without exception, yellow staining and thickening of the Rangpur rootstock bark, and they were marafivirus-positive in leaves and bark. In addition, 16 of the 17 CSD-positive indicator plants showed leaf symptoms. Of the initial $2 \times 20$ uncaged indicator plants, 12 had to be pulled out because they became severely affected with CVC (6). None of the $2 \times 20$ caged indicator plants became affected with CVC, indicating that the cages protected the indicator plants efficiently against infection with $X$. fastidiosa by sharpshooter vectors. However, 2 of the 40 caged indicator plants (5\%) became infected with CSD, based on bark symptoms and positive marafivirus detection in leaves and bark, showing incidentally that the environment within the cages was suitable for CSD symptoms to develop. These two indicator plants were probably infected during temporary opening of the cages for repair and various horticultural operations or by putative outside insect vectors feeding through the anti-aphid screen on leaves that, inside the cage, were touching the screen. In any case, 38 of the 40 caged indicator plants $(95 \%)$ were free of CSD as based on the absence of bark symptoms and lack of detection of the marafivirus in leaves and bark. These results strongly suggest that under natural conditions, CSD is transmitted by an aerial vector, such as an insect, the cages protecting most indicator plants against infection by the vector. On the basis of epidemiology studies, it has been suggested that CSD is spread in time and space in a manner similar to the spread of CTV by $T$. citricida, the major aphid vector of CTV in SPS $(1,2)$. Interestingly, the marafivirus has been detected in T. citricida, Aphis gossypii, and A. spiraecola (10). However, marafiviruses are not known to be transmitted by aphids. Since CTV is present in all citrus trees in SPS, it has been suggested that the marafivirus might be co-transmitted with CTV by the aphids, using CTV as a helper virus $(5,12)$. For instance, Potato aucuba mosaic virus (PAMV), a potexvirus, can be transmitted by aphids from plants co-infected with a potyvirus, but not from plants infected with PAMV alone (12). Leafhoppers are the natural vectors for marafiviruses (11). The marafivirus has been detected in leafhoppers in the CSD-affected region, but not in the CSD-free region (N. A. Wulff, unpublished).

In this work, the number of sweet orange indicator plants on Rangpur that developed yellow staining and thickening of the Rangpur rootstock bark as a consequence of graft transmission or natural transmission amounts to 66 and 19 , respectively. Of these 85 indicator plants with bark symptoms, 55 were examined also for marafivirus infection, and the virus was detected in every one of the 55 plants. This $100 \%$ correspondence between the marafivirus and CSD for experimentally infected trees is the highest ever reported. Similarly, of 351 symptomatic trees naturally infected with CSD, 350 trees $(99.7 \%)$ were found to be infected with the marafivirus (10). In spite of this high correspondence, the role of the marafivirus in CSD has not yet been elucidated, as Koch's postulates remain to be fulfilled. However, indisputably, the marafivirus is an excellent marker of CSD. Regarding CTV, it is not surprising that all graft-inoculated indicator plants, whether they developed CSD symptoms or not, carry the tristeza virus, because all inoculum donor trees used, whether they were from the CSD-affected region or the CSD-free region, carry CTV, as do all other outdoor citrus trees in SPS and MGS. Contrary to the CTV situation, the marafivirus has only been detected in the CSD- affected region. The role of CTV in CSD, if any, could be to help transmission of the CSD agent(s) from citrus to citrus by aphids, once the marafivirus has gained access into citrus possibly by leafhoppers, the natural vectors of marafiviruses.

In conclusion, the experiments reported here show that the agent(s) of CSD is graft-transmissible and has an aerial vector. These features are characteristic of viruses and endogenous bacteria. As the search for endogenous bacteria has been negative $(1,4,12)$, only viruses seem to be left as possible causal agents of CSD.

\section{Acknowledgments}

We are pleased to thank Luis Fernando Girotto, Antonio Ricardo Violante, Ricardo Cerqueira da Silva, José Antonio da Silva, and Miguel Antonio Mendes for the help that they have given us so generously. We thank Eduardo Sanches Stuchi from EECB for providing CSD-free buds. We are grateful to CNPq for partial support of this work (Project 500043/02-7).

\section{Literature Cited}

1. Bassanezi, R. B., Bergamin Filho, A., Amorim, L., Gimenes-Fernandes, N., Gottwald, T. R., and Bové, J. M. 2003. Spatial and temporal analyses of citrus sudden death as a tool to generate hypotheses concerning its etiology. Phytopathology 93:502-512.

2. Bassanezi, R. B., Bergamin Filho, A., Amorim, L., and Gottwald, T. R. 2005. Spatial and temporal analyses of Citrus Sudden Death in Brazil. Pages 217-229 in: Proc. Conf. IOCV, 16th. M. E. Hilf, N. Duran-Vila, and M. A. Rocha-Peña, eds. IOCV, Riverside, CA

3. Bassanezi, R. B., Gimenes-Fernandes, N., and Massari, C. A. 2006. Progresso da Morte Súbita dos Citros no Estado de São Paulo no período 2002-2005. Laranja 27:13-29.

4. Bassanezi, R. B., Gimenes-Fernandes, N., and Yamamoto, P. T. 2003. Morte Súbita dos Citros. Boletim Citrícola 24. Fundecitrus, Araraquara.

5. Bové, J. M. 2005. In retrospect: Citrus Sudden Death, a graft-transmissible, tristeza-like bud union disease. Pages 213-216 in: Proc. Conf. IOCV, 16th M. E. Hilf, N. Duran-Vila, and M. A. Rocha-Peña, eds. IOCV, Riverside, CA.

6. Bové, J. M., and Ayres, A. J. 2007. Etiology of three recent diseases of citrus in São Paulo State: Sudden death, variegated chlorosis, and huanglongbing. IUBMB Life 59: 346-354

7. Coletta Filho, H. D., Targon, M. L. P. N., Takita, M. A., Müller, G. W. Santos, F. A., Dorta, S. O., de Souza, A. A., Astúa-Monge, G., FreitasAstúa, J., and Machado, M. A. 2005. Citrus tristeza virus variant associated with citrus sudden death and its specific detection by RT-PCR. Page 499 in: Proc. Conf. IOCV, 16th. M. E. Hilf, N. Duran-Vila, and M. A. Rocha-Peña, eds. IOCV, Riverside, CA.

8. Derrick, K. S., Beretta, M. J., Barthe, G. A., Kayim, M., and Harakava, R 2003. Identification of strains of Citrus tristeza virus by subtraction hybridization. Plant Dis. 87:1355-1359.

9. Gimenes-Fernandes, N., and Bassanezi, R. B. 2001. Doença de causa desconhecida afeta pomares cítricos no norte de São Paulo e sul do Triângulo Mineiro. Sum. Phytopathol. 27:93.

10. Maccheroni,W., Alegria, M. C., Greggio, C. C., Piazza, J. P., Kamla, R. F. Zacharias, P. R. A., Bar-Joseph, M., Kitajima, E. W., Assumpção, L. C. Camarotte, G., Cardozo, J., Casagrande, E. C., Ferrari, F., Franco, S. F., Giachetto, P. F., Girasol, A., Jordão, H., Jr., Silva, V. H. A., Souza, L. C. A. Aguilar-Vildoso, C. I., Zanca, A. S., Arruda, P., Kitajima, J. P., Reinach, F. C., Ferro, J. A., and da Silva, A. C. R. 2005. Identification and genomic characterization of a new virus (Tymoviridae Family) associated with citrus sudden death disease. J. Virol. 79:3028-3037.

11. Martelli, G. P., Sabanadzovic, S., Abouh-Ghanem Sabanadzovic, N Edwards, M. C., and Dreher, T. 2002. The family Tymoviridae. Arch. Virol. 147:1837-1846

12. Román, M. P., Cambra, M., Juárez, J., Moreno, P., Duran-Vila, N. Tanaka, F. A. O., Alves, E., Kitajima, E. W., Yamamoto, P. T., Bassanezi, R. B., Teixeira, D. C., Jesus Junior, W. C., Ayres, A. J., GimenesFernandes, N., Rabenstein, F., Girotto, L. F., and Bové, J. M. 2004. Sudden death of citrus in Brazil: A graft-transmissible bud union disease. Plant Dis. 88:453-467.

13. Roy, A. and Ramachandran, P. 2002. Bi-directional PCR-a tool for identifying strains of citrus tristeza virus. Indian Phytopathol. 55:182-186.

14. São Paulo (Secretaria de Agricultura do Estado). 1974. Zoneamento agrícola do Estado de São Paulo. São Paulo v. 1.

15. Schneider, H. 1954. Anatomy of bark of bud union, trunk, and roots of quick-decline-affected sweet orange trees on sour orange rootstock. Hilgardia 22:567-581

16. Souza, A. A., Takita, M. A., Santos, F. A., Locali, E. C., Müller, G. W., and Machado, M. A. 2002. Análise de haplótipos do gene do capsídeo do CTV em plantas com sintoma de morte súbita dos citros. Fitopatol. Bras. 27:S212-S213.

17. Targon, M. L. P. N., Astua-Monge, G., Freitas-Astua, J., Kishi, L., Souza, A. A., Santos, F. A., Muller, G. W., and Machado, M. A. 2004. Evaluation 
of CTV haplotypes in plants exhibiting citrus sudden death symptoms. 10th ISC Congress, abstr. P83.

18. Targon, M. L. P. N., Astua-Monge, G., Kishi, L., Freitas-Astua, J., Souza, A. A., Santos, F. A., Müller, G. W., and Machado, M. A. 2003. Avaliação de haplótipos do CTV em plantas com sintomas de morte súbita dos citros por SSCP e seqüenciamento dos genes da P20 e P23. (Abstr.) Sum. Phytopathol. 29:71-72

19. Targon, M. L. P. N., Machado, M. A., Müller, G. W., Astua-Monge, G., and Santos, F. A. 2002. (Abstr.) Avaliação de complexos de CTV em plantas afetadas por morte súbita dos citros. Fitopatol. Bras. (Suppl.) 27:S213.

20. Yamamoto, P. T., Jesus Junior, W. C., Bassanezi, R. B., Sanches, A. L., Ayres, A. J., Gimenes-Fernandes, N., and Bové, J. M. 2003. Transmission of the agent inducing symptoms of citrus sudden death by graft-inoculation under insect proof conditions. (Abstr.) Fitopatol. Bras. (Suppl.) 28:S265.

21. Yamamoto, P. T., Jesus Junior, W. C., Bassanezi, R. B., Sanches, A. L., Ayres, A. J., Gimenes-Fernandes, N., and Bové, J. M. 2004. Transmission of the Citrus Sudden Death agent by graft-inoculation under insect proof conditions. (Abstr.) Fitopatol. Bras. (Suppl.) 29:S206. 